\title{
Prevalence of symptoms of asthma, rhinitis and eczema in 13- to 14-year-old children in Africa: the International Study of Asthma and Allergies in Childhood Phase III
}

\author{
N. Ait-Khaled ${ }^{1}$, J. Odhiambo ${ }^{2}$, N. Pearce ${ }^{3}$, K. S. Adjoh ${ }^{4}$, I. A. Maesano ${ }^{5}$, B. Benhabyles ${ }^{6}$, Z. Bouhayad ${ }^{7}$, E. \\ Bahati $^{8}$, L. Camara ${ }^{9}$, C. Catteau ${ }^{10}$, A. El Sony ${ }^{11}$, F.O. Esamai ${ }^{12}$, I. E. Hypolite ${ }^{13}$, K. Melaku ${ }^{14}$, O. A. Musa ${ }^{15}$, L.

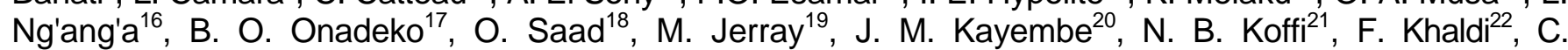 \\ Kuaban $^{23}$, K. Voyi ${ }^{24}$, J. M'Boussa $^{25}$, O. Sow ${ }^{26}$, O. Tidjani ${ }^{27}$, H. J. Zar ${ }^{28}$
}

${ }^{1}$ International Union Against Tuberculosis and Lung Disease, Paris, France (ISAAC Regional Coordinator for Africa 'French-speaking' countries); ${ }^{2}$ CDC/GAP, Nairobi, Kenya (ISAAC Regional Coordinator for Africa 'English-speaking' countries); ${ }^{3}$ Centre for Public Health Research, Massey University, Wellington, New Zealand (ISAAC Executive Committee); ${ }^{4}$ University Hospital of Lome, Togo [ISAAC Principal Investigator Lome (Togo)]; ${ }^{5}$ EPAR, U707 INSERM, Paris, France; UMR-S 707 UPMC Paris 6 , Paris, France; Medical School St-Antoine National coordinator, Reunion Island (Reunion Island): ${ }^{6}$ Centre Hospitalo Universitaire Mustapha, Algiers, Algeria [Principal Investigator Algiers (Algeria)]; ${ }^{7}$ Centre Hospitalo Universitaire, Casablanca, Morocco (Principal Investigator Benislimane, Boulmene, Casablanca, Marrakech (Morocco)]; ${ }^{8}$ National Tuberculosis Program, Kinshasa, Democratic Republic of Congo [ISAAC National Coordinator Kinshasa (Democratic Republic of Congo)]; ${ }^{9}$ Centre Hospitalo Univeristaire Ignace Deen, Conakry, Guinea [ISAAC National Coordinator Conakry (Guinea)]; ${ }^{10}$ DRASS, St Denis, [Principal Investigator, Reunion Island]; ${ }^{11}$ Epilab Director, AMST, EPILAB, Khartoum (Sudan) [National Coordinator Khartoum (Sudan)]. ${ }^{12}$ Department of Child Health and Paediatrics, Moi University [Principal Investigator Eldoret (Kenya)]. ${ }^{13}$ Hopital Regional de Port-Gentil, Port-Gentil, Gabon [Principal Investigator Port Gentil (Gabon)]; ${ }^{14}$ Department of Internal Medicine, Faculty of Medicine, Addis Ababa University, Ethiopia [Principal Investigator Addis Ababa (Ethiopia)]; ${ }^{15}$ Faculty of Medicine, National Ribat University [Principal Investigator Khartoum (Sudan)]; ${ }^{16}$ Centres for Disease Control \& Prevention (CDC) [Principal Investigator Nairobi (Kenya)]; ${ }^{17}$ Department of Medicine, University College Hospital [Principal Investigator Ibadan (Nigeria)]; ${ }^{18}$ Faculty of Medicine, National Ribat University [Principal Investigator Khartoum (Sudan)]; ${ }^{19}$ Centre Hospitalo Universitaire, Sousse, Tunisia (Principal Investigator Sousse); ${ }^{20}$ Centre Hospitalo Universitaire, Kinshasa [Principal Investigator Kinshasa (Democratic Republic of Congo)] ${ }^{21}$ Hopital de Cocody, Abidjan, Ivory Coast (Principal Investigator Urban Ivory Coast); ${ }^{22} \mathrm{H} 6 \mathrm{pital}$ d'Enfants, Tunis Jebbari, Tunisia (Principal Investigator Grand Tunis); ${ }^{23} \mathrm{H} 6$ pital Jamot, Yaounde, Cameroon (ISAAC Principal Investigator Yaounde); ${ }^{24}$ Centre Hospitalo Universitaire, Brazzaville, Congo (ISAAC Principal Investigator Brazzaville); ${ }^{25}$ Department of Environmental and Occupational Health, School of Health Systems and Public Health, University of Pretoria, South Africa; ${ }^{26}$ Centre Hospitalo Universitaire Ignace Deen, Conakry, Guinea [ISAAC National Coordinator Conakry (Guinea)]; ${ }^{27}$ Centre Hospitalo Universitaire, Lome, Togo (ISAAC National Coordinator Lome); ${ }^{28}$ Red Cross Children's Hospital, University of Cape Town (Principal Investigator Cape Town), Cape Town, South Africa

Phase I of the International Study of Asthma and Allergies in Childhood has provided valuable information regarding international prevalence patterns and potential risk factors in the development of asthma, allergic rhinoconjunctivitis and eczema. However, in Phase I, only six African countries were involved (Algeria, Tunisia, Morocco, Kenya, South Africa and Ethiopia). Phase III, conducted 5-6 years later, enrolled 22 centres in 16 countries including the majority of the centres involved in Phase I and new centres in Morocco, Tunisia, Democratic Republic of Congo, Togo, Sudan, Cameroon, Gabon, Reunion Island and South Africa. There were considerable variations between the various centres of Africa in the prevalence of the main symptoms of the three conditions: wheeze (4.0-21.5\%), allergic rhinoconjunctivitis (7.2-27.3\%) and eczema (4.7- 23.0\%). There was a large variation both between countries and between centres in the same country. Several centres, including Cape Town (20.3\%), Polokwane (18.0\%), Reunion Island (21.5\%), Brazzaville (19.9\%), Nairobi (18.0\%), Urban Ivory Coast $(19.3 \%)$ and Conakry (18.6\%) showed relatively high asthma symptom prevalences, similar to those in western Europe. There were also a number of centres showing high symptom prevalences for allergic rhinocon-junctivitis (Cape Town, Reunion Island, Brazzaville, Eldoret, Urban Ivory Coast, Conakry, Casablanca, Wilays of Algiers, Sousse and Eldoret) and eczema (Brazzaville, Eldoret, Addis Ababa, Urban Ivory Coast, Conakry, Marrakech and Casablanca).

The high burden of infectious diseases and particularly tuberculosis, AIDS and malaria in Sub-Saharan African countries where resources are scarce, has meant that asthma has not been considered as a health priority by governments, research funders and researchers. In addition, previous studies in Africa (1-11), based on limited and noncomparable methods, have generally indicated that asthma prevalence was relatively low in the majority of countries. The first random population survey conducted in adults using the same methodology within several centres in Europe and two centres in developing countries (Bombay and Algeria) showed large variation of asthma prevalence with the highest prevalence in industrialized countries. However, Bombay and Algiers showed similar asthma symptom prevalence to that observed in some European centres (12). Phase I of the International Study of Asthma and Allergies in Childhood (ISAAC) was conducted worldwide in 156 centres in 56 countries used standardized methodology (13). The use of a rigorous but simple methodology enabled investigators from developing countries to participate, including eight centres from six countries in Africa (14). A large variation of the prevalence of asthma, rhinocon-junctivitis and eczema symptoms within countries and within centres was observed (15-19), and the prevalence of symptoms found in the eight Africa centres was similar to that 
in many of the European centres.

The aims of ISAAC Phase III, conducted 6-7 years later using the same questionnaires and the same methodology as Phase I, were to estimate time trends (in those centres that had conducted to Phase I survey), and to include additional centres to yield a more complete world map of symptoms of asthma, rhinoconjunctivitis and eczema. An environmental questionnaire was added to investigate the role of a number of potential risk factors. Phase III has included a number of new centres in Africa, including new centres in Morocco, Tunisia, Democratic Republic of Congo, Togo, Sudan, Cameroon, Gabon, Reunion Island and South Africa. These centres are located in some of the poorest countries of the world and the findings are therefore of considerable interest globally, as well as within Africa. In this study, we present the new African maps for the prevalence of symptoms of asthma, rhinoconjunctivitis and eczema.

\section{Methods}

The methodology of ISAAC Phase III has been described elsewhere (19) and the core questionnaire used was detailed in the previous ISAAC Phase I publications (14-18). The ISAAC Phase III study involved both centres that had participated in Phase 1 (Phase IIIA centres) and 'Late Phase I' centres that conducted the survey too late to be included in the Phase I analysis. It also included new centres that had not previously participated (Phase IIIB centres). It was specified that each centre should involve a random sample of at least 3000, 13- to 14-year-old children, with the option of also recruiting 3000 6- to 7-year-old children.

\section{Participating centres}

The ISAAC Phase III study conducted in Africa, was coordinated by two regional coordinators - one for francophone Africa (Nadia Ait-Khaled) and one for Anglophone Africa (Joseph Odhiambho). Three types of centres are included.

- Phase IIIA centres: Five 'English-speaking' centres (Addis Ababa in Ethiopia, Nairobi and Eldoret in Kenya, Cape Town in South Africa, Ibadan in Nigeria), and four 'French-speaking' centres (Algiers in Algeria, Sousse in Tunisia, Casablanca and Marrakech in Morocco).

- Late Phase I centres: One 'French-speaking' centre (Conakry in Guinea).

- Phase IIIB centres: One 'English-speaking' centre (Polokwane in South Africa), and 11 'Frenchspeaking' centres (Kinshasa in Republic Democratic of Congo, Lome in Togo, Khartoum in Sudan, Brazzaville in Congo, Yaounde in Cameroon, Port Gentil in Gabon, Reunion Island, Grand Tunis in Tunisia, Boulmene and Benislimane in Morocco, Urban Ivory Coast in Ivory Coast).

Thus, the study involved a total of 22 centres in 16 countries. The survey involved selecting a defined geographical area and taking a random sample of school children from that area. In most cases, these were urban centres. However, in Morocco a range of different geographic environments was chosen: two big cities (Casablanca and Beni Slimane), one centre in the desert (Marrakech) and one centre located in a rural area (Boulmene; 20). In Tunisia only one centre was included in Phase I and another centre located in the capital was also included in Phase III (21). In Kenya and in South Africa other centres than the capital were involved (Eldoret and Polokwane). Reunion Island has a total different environment because it is an island, with a relatively higher standard of living as a 'French overseas department'. 


\section{openUP - October 2007}

Table 1. Characteristics of participating centres ISAAC Phase III in Africa and response rates for children 13-14 year olds (written questionnaire)

\begin{tabular}{|c|c|c|c|c|c|c|c|}
\hline $\begin{array}{l}\text { Countries } \\
\text { (centres) }\end{array}$ & $\begin{array}{l}\text { Period } \\
\text { of data } \\
\text { collection }\end{array}$ & $\begin{array}{l}\text { Principal } \\
\text { Investigator }\end{array}$ & Sampling frame & $\begin{array}{l}\text { Number of } \\
\text { schools }\end{array}$ & $\begin{array}{l}\text { Selection } \\
\text { of } \\
\text { children }\end{array}$ & $\begin{array}{l}\text { Number of } \\
\text { grades/levels or } \\
\text { years of age selected }\end{array}$ & $\begin{array}{l}\text { Number of } \\
\text { participants } \\
\text { [response rate (\%)] }\end{array}$ \\
\hline \multicolumn{8}{|l|}{ Algeria } \\
\hline Wilaya of Algiers & April-May 2002 & Badia Benhabyles & $\begin{array}{l}\text { A random sample of middle schools in Algiers } \\
\text { Department. The sampling frame is exactly the } \\
\text { same as the sampling frame in Phase I }\end{array}$ & 20 & Grade/level & 1 & $4203(89.6)$ \\
\hline \multicolumn{8}{|c|}{ 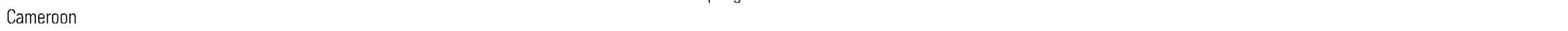 } \\
\hline Yaounde & May 2003 & C. Kuaban & $\begin{array}{l}\text { All secondary and high schools in the Bafoussam } \\
\text { Municipality }\end{array}$ & 12 & Grade/level & 3 & $2983(90.6)$ \\
\hline \multicolumn{8}{|c|}{ - } \\
\hline Brazzaville & $\begin{array}{l}\text { November } \\
\text { 2002-March } 2003\end{array}$ & J. M'Boussa & Some schools in Brazzaville region & 16 & Age group & 1 & $1012(87.3)$ \\
\hline \multicolumn{8}{|l|}{ Ivory Coast } \\
\hline Urban Ivory Coast & May-June 2001 & N. B. Koffi & All children in the schools except white children & 9 & Age group & 3 & $3342(82.5)$ \\
\hline \multicolumn{8}{|c|}{ (2) } \\
\hline Addis Ababa & June 2003 & K. Melaku & $\begin{array}{l}\text { All schools in the city of Addis Ababa, the same } \\
\text { sampling frame as Phase I }\end{array}$ & 28 & Grade/level & 1 & $3195(96.8)$ \\
\hline \multicolumn{8}{|c|}{ 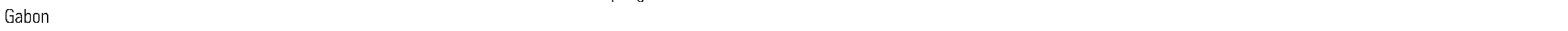 } \\
\hline Port-Gentil & May 2002-June 2003 & I. E. Hypolite & $\begin{array}{l}\text { All secondary schools and primary schools except } \\
\text { one secondary and one primary schools where } \\
\text { white children were the majority }\end{array}$ & 21 & Age group & 2 & $3166(78.7)$ \\
\hline \multicolumn{8}{|c|}{ 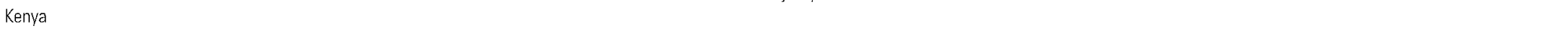 } \\
\hline Eldoret & February-April 2001 & F. 0. Esamai & $\begin{array}{l}\text { All schools in Aiwabkoi, Kapsaret and Kesses } \\
\text { Divisions in Uasin Gishu District. The same } \\
\text { sampling frame as Phase I }\end{array}$ & 72 & Age group & 2 & $3289\langle 100.0\rangle$ \\
\hline Nairobi & February-March 2001 & L. Ng'ang'a & $\begin{array}{l}\text { All Public schools under the jurisdiction of the } \\
\text { school Board of the Nairobi City Council. The } \\
\text { same sampling frame as Phase I }\end{array}$ & 15 & Grade/level & 2 & $3023(99.7)$ \\
\hline \multicolumn{8}{|c|}{$e_{1}$} \\
\hline Benslimane & November 1999 & Z. Bouhayad & $\begin{array}{l}\text { All junior high schools of Benslimane (which is a } \\
\text { rural area) }\end{array}$ & 5 & Age group & 2 & $1008\langle 100.0\rangle$ \\
\hline Boulmene & January-March 2002 & Z. Bouhayad & All Junior High Schools in Boulemene & 9 & Age group & 2 & $1254(100.0)$ \\
\hline Casablanca & October 2001 & Z. Bouhayad & $\begin{array}{l}\text { Some schools in Casablanca. The same sampling } \\
\text { frame was used for both Phase I and Phase III }\end{array}$ & 13 & Age group & 2 & $1777(100.0)$ \\
\hline Marrakech & February 2002 & Z. Bouhayad & $\begin{array}{l}\text { The same sampling frame was used for Phase I } \\
\text { and Phase III }\end{array}$ & 9 & Age group & 2 & $1689(99.9)$ \\
\hline \multicolumn{8}{|c|}{ 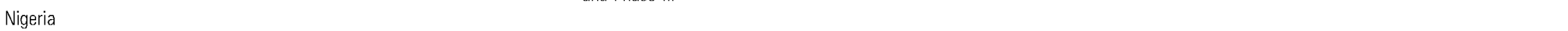 } \\
\hline |badan & May 2001-June 2002 & B. 0. Onadeko & All secondary schools in Ibadan. & 23 & Grade/level & 2 & $3142(99.7)$ \\
\hline \multicolumn{8}{|c|}{ 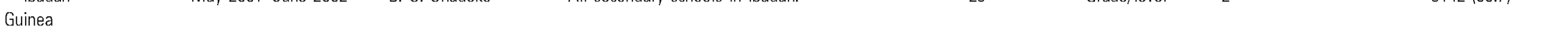 } \\
\hline Conakry & $\begin{array}{l}\text { September } 1996- \\
\text { December } 1997\end{array}$ & 0. Sow & Public and Private schools in Conakry & 44 & Age group & 2 & $3115\langle 98.1)$ \\
\hline \multicolumn{8}{|c|}{ Democratic Republic of Congo } \\
\hline Kinshasa & May 2003 & & Schools that had 13- to 14 -year-old pupils & 73 & Age group & 2 & $2930(92.9)$ \\
\hline \multicolumn{8}{|l|}{ Reunion Island } \\
\hline Reunion Island & May 2000 & I. Annesi Maesano, & $\begin{array}{l}\text { Random sample of state junior high schools. } \\
\text { Private junior high schools were not included }\end{array}$ & 37 & Grade/level & 2 & $2362(78.1)$ \\
\hline
\end{tabular}




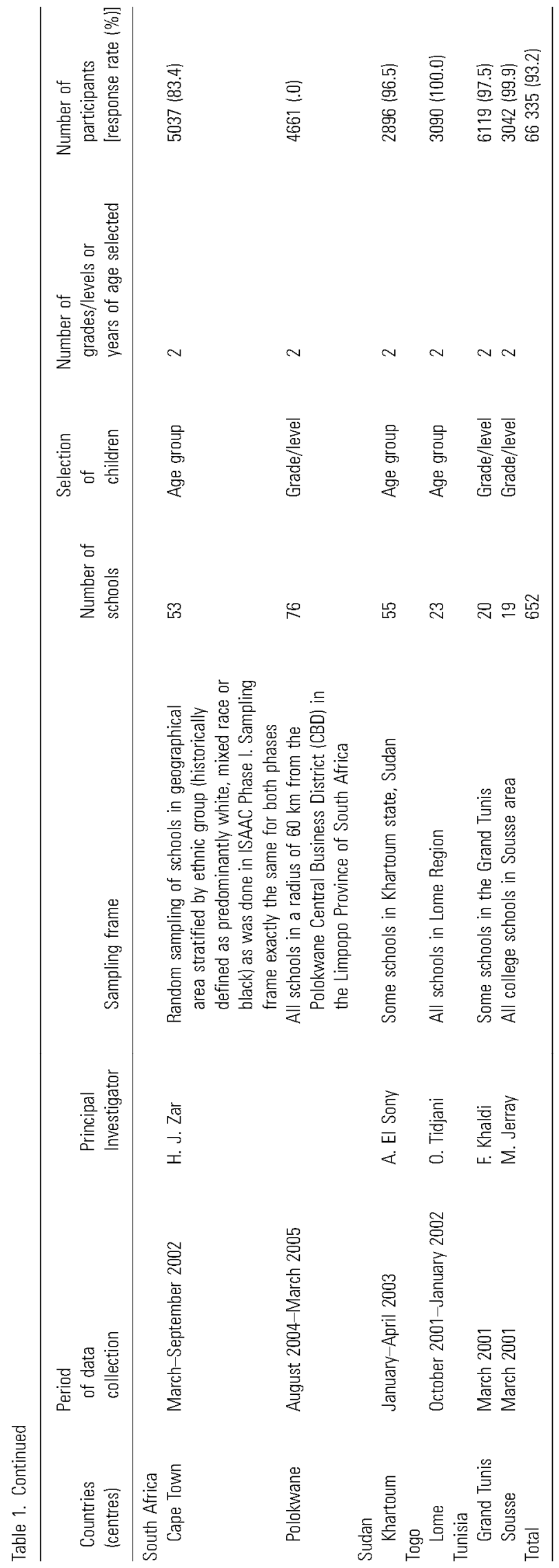

\section{Questionnaires}

The ISAAC written questionnaire for the 13- to 14-yearold age group, was self-completed at school. The key question used for assessing asthma symptom prevalence ('current wheeze') was: 'Have you had wheezing or whistling in the chest in the last 12 months'? Asthma severity was assessed by three questions relating to symptoms in the last 12 months: the number of attacks of wheezing; sleep disturbed due to wheezing and wheezing severe enough to limit speech. The rhinitis questionnaire involved six questions; allergic rhinoconjunctivitis was defined by positive answers to two questions; 'Have you had problems with sneezing or a runny or blocked nose when you did not have a cold or the flu in the last 12 months'? If yes, 'Was this problem accompanied by itchy-watery eyes'? The question on 'hayfever' was not used, because of likely differences in diagnosis between countries; in particular this terminology is rarely used even by doctors and the pollen seasons are not very clear. Three key questions were used to assess the prevalence of eczema: 'Have you ever had an itchy rash which was coming and going for at least 6 months'? If yes: 'Have you ever had this itchy rash at any. time in the last 12 months'? If yes: 'Has this itchy rash at any time affected any of the following places: the folds of the elbows, behind the knees, in front of the ankles, under the buttocks or around the neck, ears or eyes?

The ISAAC Asthma Video Questionnaire showed five scenes of adolescents and adults with asthma symptoms: wheezing at rest, wheezing with exercise, waking with wheeze, waking with cough and a severe asthma attack. For each of the scenes, students were asked whether their breathing had 'ever' been like this. If yes: 'in the last year'? If yes: 'In the last month'?

Among 'French-speaking Africa', the centres used a French questionnaire already validated by a backtranslation and used during Phase I in France and in Africa, except for the four centres of Morocco, and the centres of Tunisia and Khartoum (Sudan) which translated the English questionnaires into Arabic. The translation was underwent by bilingual local health workers and back-translated into English independently.. Among 'English-speaking centres', two in South Africa used the English original version and two added a validated questionnaire in local languages (Afrikaans and Xhosa in Cape Town; Africaans and North Sotho in Polokwan). 
Table 2. Participant characteristics of participants ISAAC Phase III, children 13-14 vear olds (written questionnaire)

\begin{tabular}{|c|c|c|c|c|c|c|c|c|}
\hline Centre & $\begin{array}{l}\text { Male gender, } \\
\qquad N(\%)\end{array}$ & $\begin{array}{l}\text { Female gender, } \\
\qquad N(\%)\end{array}$ & $\begin{array}{c}\text { Gender data } \\
\text { available, } N(\%)\end{array}$ & $\begin{array}{c}\text { Age under } 13 \text { years, } \\
\qquad N(\%)\end{array}$ & $\begin{array}{l}\text { Age } 13-14 \\
\text { years, } N(\%)\end{array}$ & $\begin{array}{l}\text { Age over } 14 \\
\text { years, } N(\%)\end{array}$ & $\begin{array}{c}\text { Age data available, } \\
\qquad N(\%)\end{array}$ & $N$ \\
\hline \multicolumn{9}{|l|}{ Algeria } \\
\hline Wilava of Algiers (west Algiers) & $1947(46.3)$ & $2256(53.7)$ & $4203(100.0)$ & $0(0.0)$ & $4203(100.0)$ & $0(0.0)$ & $4203(100.0)$ & 4203 \\
\hline Yaounde & $1358(45.5)$ & $1625(54.5)$ & $2983(100.0)$ & $1(0.0)$ & $2982(100.0)$ & $0(0.0)$ & $2983(100.0)$ & 2983 \\
\hline \multicolumn{9}{|l|}{ Congo } \\
\hline Brazzaville & $410(40.5)$ & $602(59.5)$ & $1012(100.0)$ & $48(4.7)$ & $934(92.3)$ & $30(3.0)$ & $1012(100.0)$ & 1012 \\
\hline \multicolumn{9}{|l|}{ Ethiopia } \\
\hline Addis Ababa & $1379(43.2)$ & $1816(56.8)$ & $3195(100.0)$ & $0(0.0)$ & $3195(100.0)$ & $0(0.0)$ & $3195(100.0)$ & 3195 \\
\hline \multicolumn{9}{|l|}{ Gabon } \\
\hline Port-Gentil & $1494(47.2)$ & $1672(52.8)$ & $3166(100.0)$ & $0(0.0)$ & $3166(100.0)$ & $0(0.0)$ & $3166(100.0)$ & 3166 \\
\hline \multicolumn{9}{|l|}{ Guinea } \\
\hline Conakry & $1835(58.9)$ & $1280(41.1)$ & $3115(100.0)$ & $1(0.0)$ & $3113(99.9)$ & $1(0.0)$ & $3115(100.0)$ & 3115 \\
\hline Boulmene & $750(59.8)$ & $504(40.2)$ & $1254(100.0)$ & $34(2.7)$ & $1203(95.9)$ & $17(1.4)$ & $1254(100.0)$ & 1254 \\
\hline Casablanca & $924(52.0)$ & $853(48.0)$ & $1777(100.0)$ & $14(0.8)$ & $1753(98.6)$ & $10(0.6)$ & $1777(100.0)$ & 1777 \\
\hline Marrakech & $708(41.9)$ & $981(58.1)$ & $1689(100.0)$ & $19(1.1)$ & $1614(95.6)$ & $56(3.3)$ & $1689(100.0)$ & 1689 \\
\hline \multicolumn{9}{|l|}{ Nigeria } \\
\hline lbadan & $1796(57.2)$ & $1346(42.8)$ & $3142(100.0)$ & $99(3.2)$ & $3034(96.6)$ & $9(0.3)$ & $3142(100.0)$ & 3142 \\
\hline \multicolumn{9}{|l|}{ Democratic Republic of Congo } \\
\hline Kinshasa & $1275(43.5)$ & $1655(56.5)$ & $2930(100.0)$ & $0(0.0)$ & $2930(100.0)$ & $0(0.0)$ & $2930(100.0)$ & 2930 \\
\hline \multicolumn{9}{|l|}{ Reunion Island } \\
\hline Reunion Island & $1081(45.8)$ & $1281(54.2)$ & $2362(100.0)$ & $113(4.8)$ & $1786(76.3)$ & $442(18.9)$ & 2341 (99.1) & 2362 \\
\hline \multicolumn{9}{|l|}{ South Africa } \\
\hline Cape Town & $2026(40.4)$ & $2995(59.6)$ & $5021(99.7)$ & $1(0.0)$ & $5034(99.9)$ & $2(0.0)$ & $5037(100.0)$ & 5037 \\
\hline Polokwane & $1997(42.9)$ & $2656(57.1)$ & 4653 (99.8) & $276(5.9)$ & $3893(83.6)$ & $486(10.4)$ & $4655(99.9)$ & 4661 \\
\hline \multicolumn{9}{|l|}{ Sudan } \\
\hline
\end{tabular}

\section{Ethical issues}

In all centres the investigators obtained authorization from the Ministry of Health and from the Ministry of Education to conduct the study as well as the consent of the directors of schools. In the majority of countries, in absence of an ethics committee, agreement was obtained from the authorities of the investigators' institutions (University or Hospital). Letters to parents were distributed via schools where appropriate and parents were requested to contact the school only if they did not wish their children to participate - no contact or action from the parents was to be taken as passive consent.

\section{Data collection}

All countries had a training session for the local health staff who were to be directly involved with the 
implementation of the study. Data collection was carried out by local investigators under the guidance of the Regional Coordinator. Prior to the actual survey date, further visits to the schools served as final preparations to ascertain a manageable number of students per session as well as ensuring appropriate facilities for conducting the survey. Usually the survey was based on a random sample of schools in each centre, except for a few centres that conducted the survey in all schools (Table 1).

Table 3. Prevalence of symptoms of asthma (current wheeze and severe symptoms of asthma), rhinoconjunctivitis and eczema in the past 12 months in Africa, children 13-14 year olds (written questionnaire)

\begin{tabular}{|c|c|c|c|c|}
\hline Centre & $\begin{array}{c}\text { Current wheeze, } \\
\qquad N(\%)\end{array}$ & $\begin{array}{c}\text { Current symptoms } \\
\text { of severe asthma, } N(\%)\end{array}$ & $\begin{array}{c}\text { Current symptoms } \\
\text { of rhinoconjunctivitis, } N(\%)\end{array}$ & $\begin{array}{l}\text { Current symptoms } \\
\text { of eczema, } N(\%)\end{array}$ \\
\hline \multicolumn{5}{|l|}{ Africa (French speaking) } \\
\hline \multicolumn{5}{|l|}{ Algeria } \\
\hline Wilaya of Algiers (west Algiers) & $367(8.7)$ & $69(1.6)$ & $871(20.7)$ & $275(6.5)$ \\
\hline \multicolumn{5}{|l|}{ Cameroon } \\
\hline Yaounde & $169(5.7)$ & $46(1.5)$ & $264(8.9)$ & $215(7.2)$ \\
\hline \multicolumn{5}{|l|}{ Congo } \\
\hline Brazzaville & $201(19.9)$ & $28(2.8)$ & $337(33.3)$ & $164(16.2)$ \\
\hline \multicolumn{5}{|l|}{ Cote d'lvoire } \\
\hline Urban Ivory Coast & $645(19.3)$ & $53(1.6)$ & $921(27.6)$ & $607(18.2)$ \\
\hline \multicolumn{5}{|l|}{ Gabon } \\
\hline Port-Gentil & $324(10.2)$ & $57(1.8)$ & $523(16.5)$ & $454(14.3)$ \\
\hline \multicolumn{5}{|l|}{ Morocco } \\
\hline Benslimane & $89(8.8)$ & $19(1.9)$ & $195(19.3)$ & $122(12.1)$ \\
\hline Boulmene & $68(5.4)$ & $18(1.4)$ & $104(8.3)$ & $100(8.0)$ \\
\hline Casablanca & $285(16.0)$ & $69(3.9)$ & $500(28.1)$ & $408(23.0)$ \\
\hline Marrakech & $75(4.4)$ & $21(1.2)$ & $249(14.7)$ & $346(20.5$ \\
\hline \multicolumn{5}{|l|}{ Democratic Republlic of Congo } \\
\hline Kinshasa & $221(7.5)$ & $27(0.9)$ & $346(11.8)$ & $320(10.9)$ \\
\hline \multicolumn{5}{|l|}{ Reunion Island } \\
\hline Reunion Island & $507(21.5)$ & $53(2.2)$ & $645(27.3)$ & $324(13.7)$ \\
\hline \multicolumn{5}{|l|}{ Republic of Guinea } \\
\hline Conakry & $578(18.6)$ & $113(3.6)$ & $669(21.5)$ & $587(18.8)$ \\
\hline \multicolumn{5}{|l|}{ Sudan } \\
\hline Kharluurr & $361(12.5)$ & $160(5.5)$ & $208(7.2)$ & $137(4.7)$ \\
\hline \multicolumn{5}{|l|}{ Togo } \\
\hline Lome & $520(16.8)$ & $51(1.7)$ & $450(14.6)$ & $332(10.7)$ \\
\hline \multicolumn{5}{|l|}{ Tunisia } \\
\hline Grand Tunis & $944(15.4)$ & $318(5.2)$ & $897(14.7)$ & $793(13.0)$ \\
\hline Sousse & $362(11.9)$ & $85(2.8)$ & $706(23.2)$ & $286(9.4)$ \\
\hline Total & $5716(13.0)$ & $1187(2.7)$ & $7885(17.9)$ & $5470(12.4)$ \\
\hline \multicolumn{5}{|l|}{ Africa (English speaking) } \\
\hline \multicolumn{5}{|l|}{ Ethiopia } \\
\hline Addis Ababa & $290(9.1)$ & $66(2.1)$ & $316(9.9)$ & $606(19.0)$ \\
\hline \multicolumn{5}{|l|}{ Kenya } \\
\hline Eldoret & $455(13.8)$ & $131(4.0)$ & $738(22.4)$ & $509(15.5)$ \\
\hline Nairobi & $543(18.0)$ & $167(5.5)$ & $600(19.8)$ & $449(14.9)$ \\
\hline \multicolumn{5}{|l|}{ Nigeria } \\
\hline lbadan & $408(13.0)$ & $128(4.1)$ & $515(16.4)$ & $242(7.7)$ \\
\hline \multicolumn{5}{|l|}{ South Africa } \\
\hline Cape Town & $1025(20.3)$ & $252(5.0)$ & $1043(20.7)$ & $670(13.3)$ \\
\hline Polokwane & $838(18.0)$ & $309(6.6)$ & $846(18.2)$ & $520(11.2)$ \\
\hline Total & $3559(15.9)$ & $1053(4.7)$ & $4058(18.2)$ & $2996(13.4)$ \\
\hline
\end{tabular}




\section{Data management and analysis}

Dates of data collection were documented. In the majority of centres all data were double-entered and the two files were compared using sas. Any discrepancies between the first and second entry files were then resolved by referring to the paper questionnaire. For each centre, an ISAAC Centre Report was submitted to the IIDC. The Centre Report provided details of the local implementation of ISAAC Phase III addressing key issues including geographical definitions, sampling of schools and children, participation rates, translation of questionnaires, data management including its entry and formats during submission to the IIDC.

For the prevalence analyses, the asthma, rhinoconjunctivitis and eczema symptom prevalence for each centre were calculated by dividing the number of positive responses to each question by the number of completed questionnaires for the written and video questionnaires separately. The presented analysis will focus on the 23 centres in 16 countries coordinated by the two ISAAC regional coordinators for Africa. Except for Ibadan (Nigeria) and Polokwan (South Africa), which surveyed both 6- to 7- and the 13- to 14-year-.old children, all other African centres surveyed only the 13-14 year olds. Thus, this study will focus on the findings for 13-14 year olds.

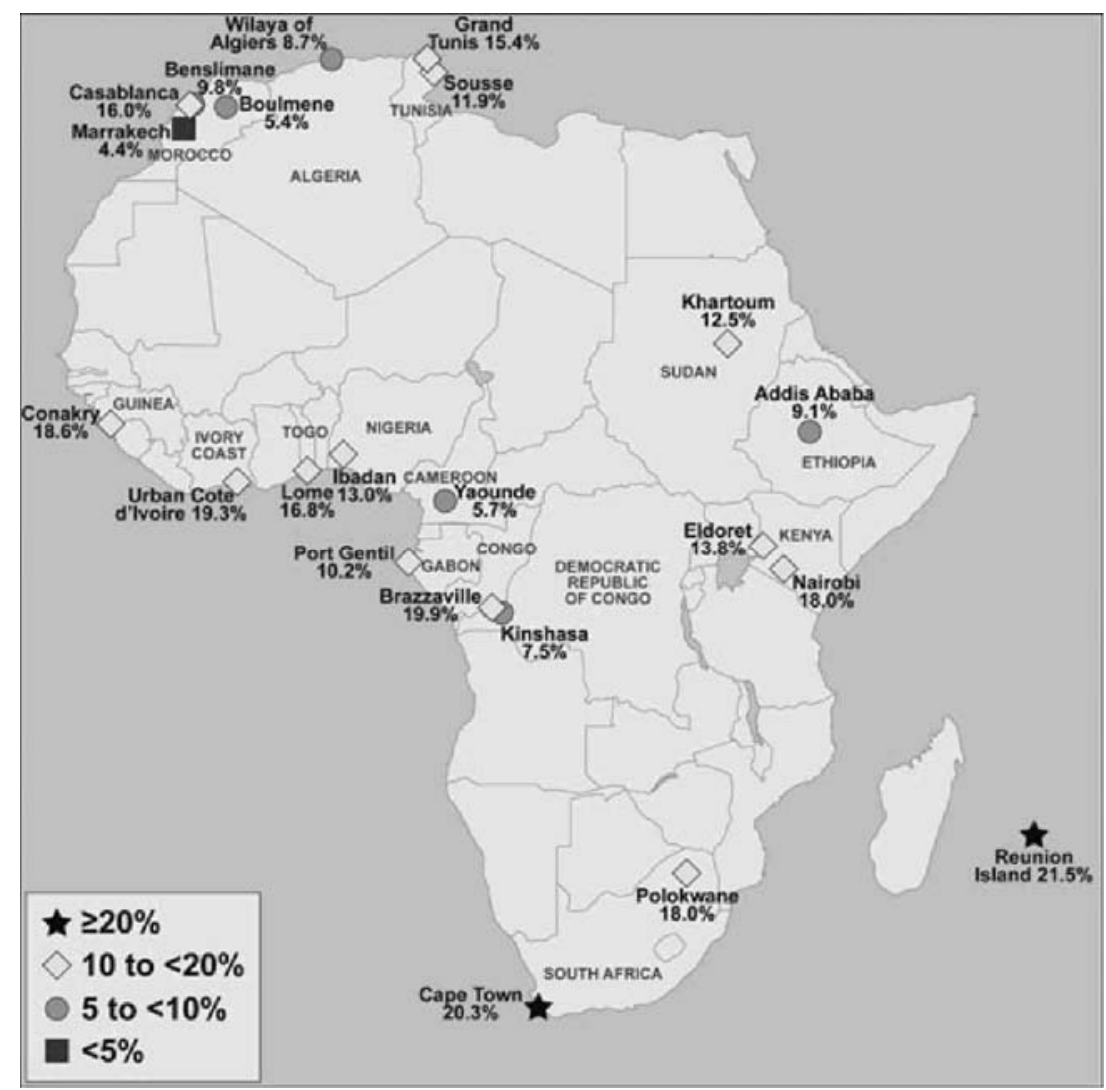

Figure 1. Prevalence of symptoms of wheeze in the past 12 months, 13-14 year age group in Africa. 
openUP - October 2007

Table 4. Prevalence of asthma symptoms in all African countries ISAAC Phase III for children 13-14 year olds (video questionnaire)

\begin{tabular}{|c|c|c|c|c|c|c|c|c|}
\hline \multirow{2}{*}{$\begin{array}{l}\text { Video questionnaire scene } \\
\text { Wheezing (while at rest) }\end{array}$} & \multicolumn{8}{|c|}{ Nairobi, $N(\%)$ Benslimane, $N(\%)$ Boulmene, $N(\%)$ Casablanca, $N(\%)$ Marrakech, $N(\%) \mid$ badan, $N(\%)$ Cape Town, $N(\%)$ Total, $N(\%)$} \\
\hline & & & & & & & & \\
\hline Ever. & $448(14.8)$ & $175(17.4)$ & $156(12.4)$ & $294(16.6)$ & $211(12.5)$ & $437(15.1)$ & $839(16.8)$ & $2560(15.4)$ \\
\hline In the last year & $326(10.8)$ & $105(10.4)$ & $89(7.1)$ & $229(12.9)$ & $146(8.7)$ & $295(10.2)$ & $559(11.2)$ & $1749(10.5)$ \\
\hline In the last month (one or more times) & $179(5.9)$ & $71(7.1)$ & $52(4.1)$ & $186(10.5)$ & $112(6.6)$ & $256(8.8)$ & $351(7.0)$ & $1207(7.3)$ \\
\hline \multicolumn{9}{|l|}{ Wheezing after exercise } \\
\hline Ever & $617(20.4)$ & $204(20.3)$ & 166 (13.2) & $402(22.7)$ & $258(15.3)$ & $810(27.9)$ & $1070(21.5)$ & $3527(21.2)$ \\
\hline In the last year & $512(16.9)$ & $114(11.3)$ & $112(8.9)$ & 299 (16.9) & $174(10.3)$ & $614(21.2)$ & $692(13.9)$ & $2517(15.1)$ \\
\hline In the last month (one or more times) & $305(10.1)$ & $70(7.0)$ & $75(6.0)$ & $233(13.2)$ & $137(8.1)$ & 549 (18.9) & $466(9.3)$ & $1835(11.0)$ \\
\hline \multicolumn{9}{|l|}{ Waking with wheeze } \\
\hline Ever & $313(10.4)$ & $89(8.8)$ & $59(4.7)$ & $192(10.8)$ & $114(6.8)$ & $225(7.8)$ & $459(9.2)$ & $1451(8.7)$ \\
\hline In the last year & $237(7.8)$ & $59(5.9)$ & $32(2.6)$ & $128(7.2)$ & $80(4.7)$ & $166(5.7)$ & $265(5.3)$ & $967(5.8)$ \\
\hline In the last month (one or more times) & $121(4.0)$ & $32(3.2)$ & $20(1.6)$ & $103(5.8)$ & $53(3.1)$ & $135(4.7)$ & $194(3.9)$ & $658(4.0)$ \\
\hline \multicolumn{9}{|l|}{ Waking with cough } \\
\hline Ever & $903(29.9)$ & $212(21.1)$ & $246(19.6)$ & $438(24.7)$ & $390(23.1)$ & $746(25.7)$ & $1501(30.1)$ & $4436(26.7)$ \\
\hline In the last year & $708(23.4)$ & $102(10.1)$ & $154(12.3)$ & $312(17.6)$ & $281(16.7)$ & $546(18.8)$ & $957(19.2)$ & $3060(18.4)$ \\
\hline In the last month (one or more times) & $369(12.2)$ & $62(6.2)$ & $85(6.8)$ & $194(11.0)$ & $160(9.5)$ & $420(14.5)$ & $620(12.4)$ & $1910(11.5)$ \\
\hline \multicolumn{9}{|l|}{ Severe wheeze } \\
\hline Ever & $292(9.7)$ & $108(10.7)$ & $87(6.9)$ & $266(15.0)$ & $184(10.9)$ & $224(7.7)$ & $603(12.1)$ & $1764(10.6)$ \\
\hline In the last year & $216(7.1)$ & $70(7.0)$ & $45(3.6)$ & $194(11.0)$ & $127(7.5)$ & $161(5.6)$ & $347(7.0)$ & $1160(7.0)$ \\
\hline In the last month (one or more times) & $116(3.8)$ & $46(4.6)$ & $26(2.1)$ & $152(8.6)$ & $100(5.9)$ & $138(4.8)$ & $216(4.3)$ & $794(4.8)$ \\
\hline Total participants for video questionnaire & 3023 & 1006 & 1254 & 1771 & 1687 & 2900 & 4986 & 16627 \\
\hline
\end{tabular}

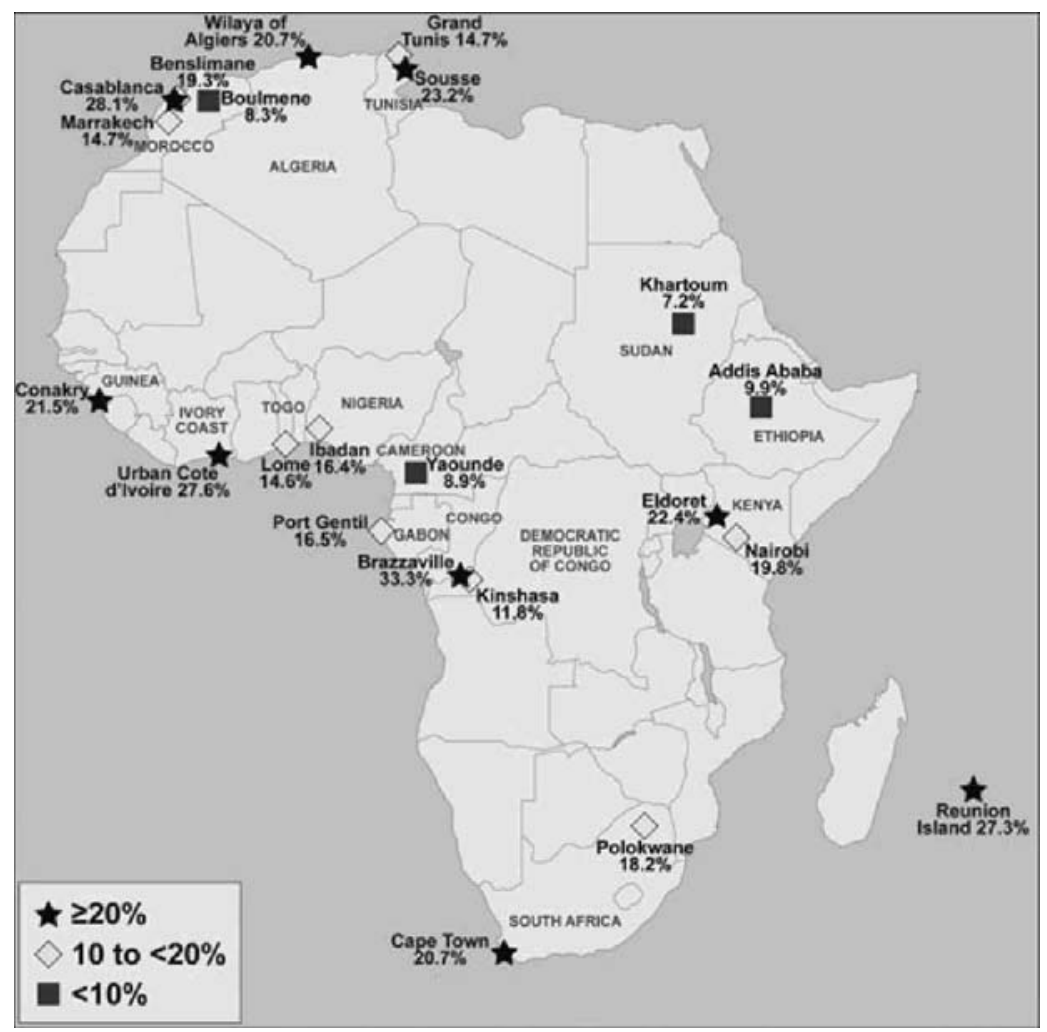

Figure 2. Prevalence of symptoms of allergic rhinoconjunctivitis in the past 12 months, 13-14 year age group in Africa 


\section{Results}

\section{Participating centres and response rates}

Table 1 shows the characteristics of participating centres including sampling frames, number of schools, selection criteria for children, age groups and levels or years selected for children's participation. All centres were registered with the ISAAC International Data Centre (IIDC) through the Regional Coordinators. Table 1 also shows the response rates among school children in the countries that participated in ISAAC Phase III and dates of data collection. The response rates varied from $78.1 \%$ to $100 \%$, with an average response rate of $93.1 \%$.

\section{Demography}

Table 2 presents the participant characteristics for surveys in 13-14 year olds. Of the 66, 335 school children that participated, 9\% were outside the 13-14 year old range. Overall, 51\% of the participants were female, but this proportion varied from $40.2 \%$ in Boulmene (Morocco) and Urban Ivory Coast to $59.6 \%$ in Cape Town (South Africa).

\section{Prevalence of reported symptoms of asthma}

Table 3 presents the (written questionnaire) prevalence findings for current symptoms of asthma, severe asthma, allergic rhinoconjunctivitis and eczema symptoms among 13-14 year olds. Overall, 13\% of the participants in French-speaking centres had wheezing in the last 12 months and 15.9\% in 'Englishspeaking' centres. The variation in current wheeze within countries and within centres in the same country is illustrated in Fig. 1. Several centres, including Cape Town (20.3\%), Polokwane (18.0\%), Reunion Island (21.5\%), Brazzaville (19.9\%), Nairobi (18.0\%), Urban Ivory Coast (19.3\%) and Conakry (18.6\%) showed relatively high asthma symptom prevalences similar to those in western Europe, whereas several centres showed low prevalence including Marrak-ech (4.4\%), Yaounde (5.7\%) and Kinshasa (7.5\%) or intermediate prevalence as Addis Ababa (9.1\%) and Algiers (8.7\%). The prevalence of severe asthma symptoms varied among centres from $0.9 \%$ in Kinshasa to $6.6 \%$ in Polokwane.

Table 4 presents the responses to the video questionnaire for asthma symptoms from the seven centres that included it. There was less variation in symptom prevalence than was observed with the written questionnaire. The lowest prevalence for current wheeze is for Marrak-ech (8.7\%) and all other centres have prevalence among $10 \%$.

\section{Prevalence of reported symptoms of allergic rhinoconjunctivitis}

As shown in Fig. 2, there was large variation of rhino-conjunctivitis prevalence within centres, and the pattern of symptom prevalence across centres was different from current wheezing. Several centres have a high prevalence of rhinoconjunctivitis (>20\%), including Cape Town and Reunion Island (which also have the highest prevalence of current wheezing) and also three centres in North Africa (Algiers, Casablanca and Sousse) and three centres in Sub-Saharan Africa (Urban Ivory Coast, Conakry and Eldoret). Only four centres had a low prevalence of rhinoconjunctivitis (<10\%; Khartoum, Yaounde, Addis Abeba and Boulmene). Except in the two centres with the highest asthma symptom prevalence levels (Cape Town and Reunion Island), the prevalence of rhinoconjunctivi-tis was always higher than the prevalence of current wheeze. 


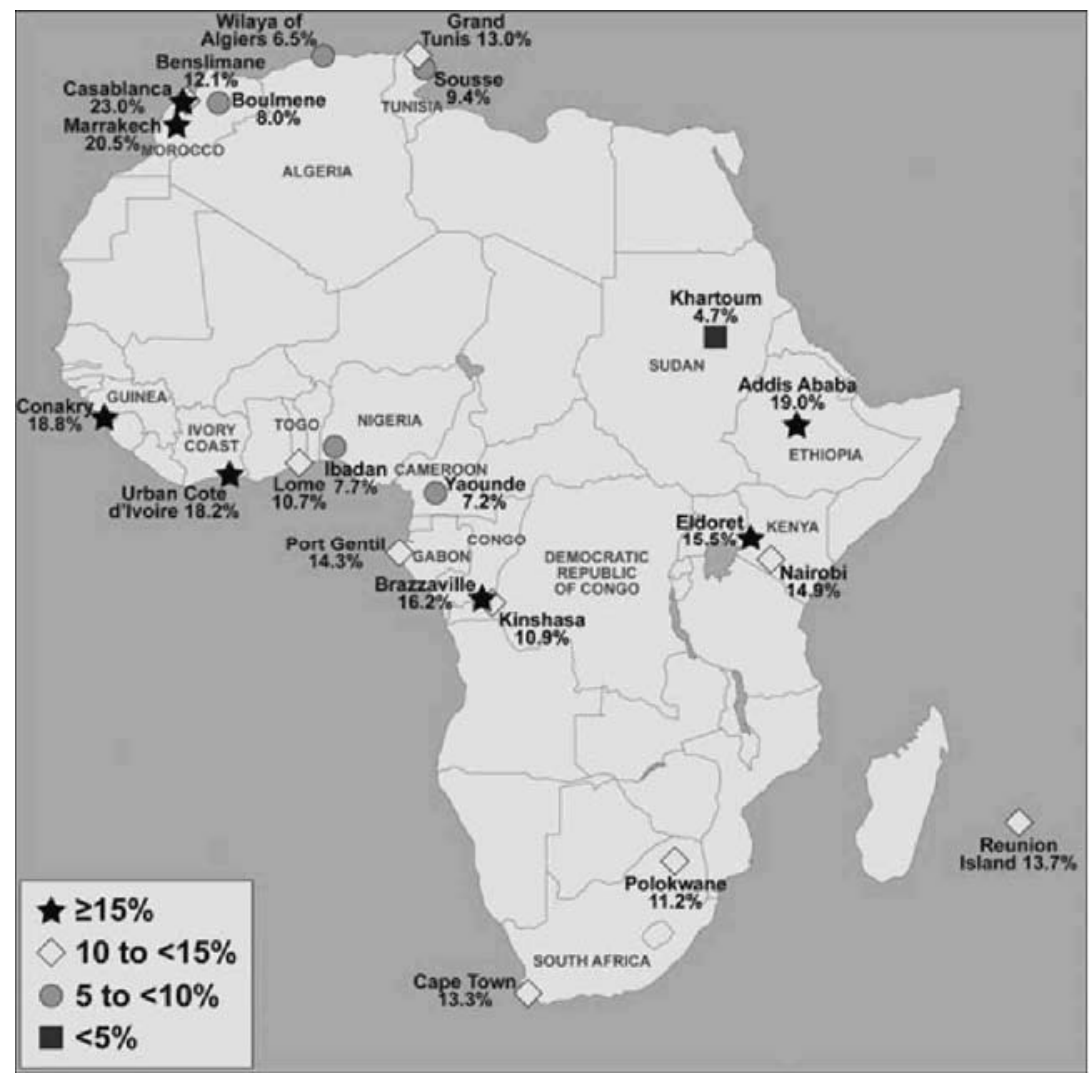

Figure 3. Prevalence of symptoms of eczema in the past 12 months, 13-14 year age group in Africa.

\section{Prevalence of reported symptoms of eczema}

As shown in Fig. 3, the distribution of prevalence of eczema symptoms is very different from current wheeze, and more similar to the map for rhinoconjunctivitis (Fig. 2). The highest prevalence of eczema $(\ddagger 15 \%)$ was found in the same centres with high prevalence of rhinoconjunctivitis in Urban Ivory Coast, Conakry and

Casablanca. Two other centres had a high prevalence of eczema symptoms: Addis Ababa with intermediate prevalence of wheezing (9.1\%) and low prevalence of rhinoconjunctivitis (9.9\%); and Marrakech which had the lowest prevalence of current wheeze (4.4\%) and a markedly higher prevalence of rhinoconjunctivitis. However, the two centres with the highest prevalence of wheeze and rhinoconjunctivitis (Cape Town and Reunion Island) had only intermediate prevalence levels for eczema symptoms, respectively, $13.7 \%$ and $13.3 \%$.

\section{Comorbidity}

Table 5 presents the comorbidity of the three conditions. The prevalence of the combination of wheeze and rhinoconjonctivitis is relatively high with an average of $3.4 \%$ in the Africa centres; the highest rates were observed in Reunion Island (6.6\%), Brazzaville (6.0\%) and Cape Town (5.8\%). 
Table 5. Combinations of symptoms of asthma, rhinoconjunctivitis and eczema in the last 12 months in Africa centres, children 13-14 year olds (written questionnaire)

\begin{tabular}{|c|c|c|c|c|c|c|c|c|}
\hline Centre & $\begin{array}{l}\text { Wheeze only, } \\
\qquad N(\%)\end{array}$ & $\begin{array}{c}\text { Rhinoconjunctivitis } \\
\text { only, } N(\%)\end{array}$ & $\begin{array}{l}\text { Eczema only, } \\
\qquad N(\%)\end{array}$ & $\begin{array}{c}\text { Wheeze and } \\
\text { rhinoconjunctivitis, } N(\%)\end{array}$ & $\begin{array}{l}\text { Wheeze and } \\
\text { eczema, } N(\%)\end{array}$ & $\begin{array}{l}\text { Rhinoconjunctivitis } \\
\text { and eczema, } N(\%)\end{array}$ & $\begin{array}{c}\text { All } 3 \text { conditions, } \\
N(\%)\end{array}$ & $N$ \\
\hline \multicolumn{9}{|l|}{ Algeria } \\
\hline Wilaya of Algiers (west Algiers) & $172(4.1)$ & $597(14.2)$ & $134(3.2)$ & $145(3.4)$ & $12(0.3)$ & $91(2.2)$ & $38(0.9)$ & 4203 \\
\hline \multicolumn{9}{|l|}{ Cameroon } \\
\hline Yaounde & $130(4.4)$ & $188(6.3)$ & $148(5.0)$ & $20(0.7)$ & $11(0.4)$ & $48(1.6)$ & $8\langle 0.3)$ & 2983 \\
\hline \multicolumn{9}{|l|}{ Congo } \\
\hline Brazzaville & $86(8.5)$ & $179(17.7)$ & $58(5.7)$ & $63(6.2)$ & $11(1.1)$ & $54(5.3)$ & $41(4.1)$ & 1012 \\
\hline \multicolumn{9}{|l|}{ Ivory Coast } \\
\hline Urban Ivory Coast & $322(9.6)$ & $500(15.0)$ & $257(7.7)$ & $154(4.6)$ & $83(2.5)$ & $181(5.4)$ & $86(2.6)$ & 3342 \\
\hline \multicolumn{9}{|l|}{ Ethiopia } \\
\hline Addis Ababa & $155(4.9)$ & $140(4.4)$ & $411(12.9)$ & $38(1.2)$ & $57(1.8)$ & $98(3.1)$ & $40\langle 1.3\}$ & 3195 \\
\hline \multicolumn{9}{|l|}{ Gabon } \\
\hline Port-Gentil & $160\langle 5.1\rangle$ & $297(9.4)$ & $257(8.1)$ & $74(2.3)$ & $45(1.4)$ & $107(3.4)$ & $45(1.4)$ & 3166 \\
\hline \multicolumn{9}{|l|}{ Kenya } \\
\hline Eldoret & $176(5.4)$ & $342(10.4)$ & $184(5.6)$ & $114(3.5)$ & $43(1.3)$ & $160(4.9)$ & $122(3.7)$ & 3289 \\
\hline Nairobi & $293(9.7)$ & $295(9.8)$ & $207(6.8)$ & $123(4.1)$ & $60(2.0)$ & $115(3.8)$ & $67(2.2)$ & 3023 \\
\hline \multicolumn{9}{|l|}{ Morocco } \\
\hline Benslimane & $18(1.8)$ & $99(9.8)$ & $47(4.7)$ & $31(3.1)$ & $10(1.0)$ & $35(3.5)$ & $30(3.0)$ & 1008 \\
\hline Boulmene & $47(3.7)$ & $80(6.4)$ & $84(6.7)$ & $12(1.0)$ & $4(0.3)$ & $7(0.6)$ & $5(0.4)$ & 1254 \\
\hline Casablanca & $93(5.2)$ & $205(11.5)$ & $178(10.0)$ & $93(5.2)$ & $28(1.6)$ & $131(7.4)$ & $71(4.0)$ & 1777 \\
\hline Marrakech & $29(1.7)$ & $138(8.2)$ & $228(13.5)$ & $13(0.8)$ & $20(1.2)$ & $85(5.0)$ & $13(0.8)$ & 1689 \\
\hline \multicolumn{9}{|l|}{ Nigeria } \\
\hline Ibadan & $254(8.1)$ & $312(9.9)$ & $93(3.0)$ & $83(2.6)$ & $29(0.9)$ & $78(2.5)$ & $42(1.3)$ & 3142 \\
\hline \multicolumn{9}{|l|}{ Republic Democratic of Congo } \\
\hline Kinshasa & $136(4.6)$ & $219(7.5)$ & $204(7.0)$ & $34(1.2)$ & $23(0.8)$ & $65(2.2)$ & $28(1.0)$ & 2930 \\
\hline \multicolumn{9}{|l|}{ Reunion Island } \\
\hline Reunion Island & $229(9.7)$ & $309(13.1)$ & $105(4.4)$ & $155(6.6)$ & $38(1.6)$ & $96(4.1)$ & $85(3.6)$ & 2362 \\
\hline \multicolumn{9}{|l|}{ Guinea } \\
\hline Conakry & $246(7.9)$ & $275(8.8)$ & $236(7.6)$ & $116(3.7)$ & $73(2.3)$ & $135(4.3)$ & $143(4.6)$ & 3115 \\
\hline \multicolumn{9}{|l|}{ South Africa } \\
\hline Cape Town & $516(10.2)$ & $506(10.0)$ & $314(6.2)$ & $293(5.8)$ & $112(2.2)$ & $140(2.8)$ & $104(2.1)$ & 5037 \\
\hline Polokwane & $432(9.3)$ & $448(9.6)$ & $249(5.3)$ & $221(4.7)$ & $94(2.0)$ & $86(1.8)$ & $91(2.0)$ & 4661 \\
\hline \multicolumn{9}{|l|}{ Sudan } \\
\hline Khartoum & $224(7.7)$ & $85(2.9)$ & $48(1.7)$ & $68(2.3)$ & $34(1.2)$ & $20(0.7)$ & $35(1.2)$ & 2896 \\
\hline \multicolumn{9}{|l|}{ Togo } \\
\hline Lome & $304(9.8)$ & $234(7.6)$ & $168(5.4)$ & $112(3.6)$ & $60(1.9)$ & $60(1.9)$ & $44(1.4)$ & 3090 \\
\hline \multicolumn{9}{|l|}{ Tunisia } \\
\hline Grand Tunis & $530(8.7)$ & $481(7.9)$ & $441(7.2)$ & $193(3.2)$ & $129(2.1)$ & $131(2.1)$ & $92(1.5)$ & 6119 \\
\hline Sousse & $178(5.9)$ & $456(15.0)$ & $122(4.0)$ & $117(3.8)$ & $31(1.0)$ & $97(3.2)$ & $36(1.2)$ & 3042 \\
\hline Total & $4730(7.1)$ & $6385(9.6)$ & $4173(6.3)$ & $2272(3.4)$ & $1007(1.5)$ & $2020(3.0)$ & $1266(1.9)$ & 66335 \\
\hline
\end{tabular}

\section{Discussion}

The ISAAC Phase III in Africa has determined the prevalence of asthma, allergic rhinoconjunctivitis and eczema symptoms in 22 centres among 16 countries using standardized methodology and instruments. The large involvement in ISAAC of centres in Africa demonstrated the possibility to involve clinicians of Africa in an international survey and provided an opportunity to establish an environment for health research in the participating countries (14). The large variation within countries and within centres in the same country demonstrated worldwide by the ISAAC Phase I results has also been shown for the Africa centres involved in Phase III. Furthermore, the patterns of symptom prevalence for asthma symptoms is different from the other two conditions, and the comorbidity of asthma and rhinoconjuncti-vitis is high in all centres. 
The prevalence of current wheeze is generally intermediate or high in the majority of centres. The lowest prevalence of current wheeze was found in two centres of a middle-income country of North Africa (Marrakech located in the desert and Boulmene located in a rural area of Morocco) and in Kinshasa, which is located in one of the poorest countries of Sub-Saharan Africa. Several centres, including Cape Town (20.3\%), Polokwane (18.0\%), Reunion Island (21.5\%), Brazzaville (19.9\%), Nairobi (18.0\%), Urban Ivory Coast (19.3\%) and Conakry (18.6\%) showed relatively high asthma symptom prevalences similar to those in western Europe. The highest prevalence of current wheeze was found in Reunion Island where a large part of the population has a higher standard of life than in other African countries. As suggested by previous studies conducted in Africa (22-25), the prevalence of current asthma was higher in urban than in rural areas. In countries where several centres were involved, the prevalence of current wheeze was generally the highest in urban centres (Casablanca in Morocco, Grand Tunis in Tunisia, Nairobi in Kenya, Cape Town in South Africa). This could be explained by several environmental factors linked with urbanization and the adoption of 'western life style' (26) by a part of the population with the highest socioeconomic level living in urban centres.

The intermediate levels of prevalence of current wheeze found in several centres located in countries of Sub-Saharan Africa (Conakry, Urban Ivory Coast, Brazzaville, Khartoum, Nairobi, Polokwane) with high levels of parasites, and infections (particularly tuberculosis and HIVIAIDS) are particularly surprising and are not in concordance with the protective role of parasites $(27,28)$ or with the 'hygienic hypothesis' $(29)$.

The pattern of variation in prevalence of severe asthma within countries is not strongly correlated with the prevalence of current wheeze, and could be explained more by the awareness of the disease and the level of asthma management than by specific asthma risk factors.

The high or intermediate prevalence of rhinoconjunc-tivitis and eczema symptoms found in the majority of the centres of Africa is raises a number of questions. One hypothesis emerging from the preliminary findings of ISAAC Phase II is that, in centres located in developing countries, a large proportion of chronic rhinoconjuncti-vitis and eczema cases are caused by nonallergic factors (30). The high reported prevalence of eczema must also be regarded with caution, taking into account the possible confusion of eczema symptoms with other itchy diseases that are common in Africa.

In conclusion, ISAAC Phase III in Africa has expanded on the findings of ISAAC Phase I. The findings are of particular interest, as many countries have to some extent retained their traditional diet and lifestyles but are becoming increasingly 'westernized', particularly in 'urban' areas. There are also, except in North Africa, very high prevalences of tuberculosis, HIVIAIDS, parasites and infections in young children, and other risk factors (e.g. particular allergens and endotoxin) that may be 'specific' to Africa. Overall, the prevalence estimates are relatively high, with a number of centres showing prevalences for current wheeze that are similar to those that have been reported in European countries (31). These findings have demonstrated for the first time that asthma is an emerging public health problem in Africa. This epidemiological evidence could be an important first step to increasing political involvement of decision-makers, researchers and potential research funders to invest more in asthma research projects and in the prevention and management of asthma in Africa. 


\section{References}

1. Belhocine M, Ait-Khaled N. Prevalence of asthma in a region of Algeria. Bull Int Union Tuberc Lung Dis 1991;66:91-93.

2. Att-Khaled N. Donnees epidemiologiques sur l'asthme au Maghreb; dans 'L'asthme de l'adulte, Donnees actuelles'. Algerie: ENAG -Editions Sante, 1992.

3. Melaku K, Berhane Y. Prevalence of wheeze and asthma related symptoms among school children in Addis Ababa, Ethiopia. Ethiop Med J 1999;37: 247-254.

4. Nriagu J, Robins T, Gary L, Liggans G, Davila R, Supuwood K et al. Prevalence of asthma and respiratory symptoms in south-central Durban, South Africa. Eur J Epidemiol 1999;15:747-755.

5. Falade AG, Olawuyi F, Osinusi K, Onadeko BO. Prevalence and severity of symptoms of asthma, allergic rhino-conjunctivitis and atopic eczema in secondary school children in Ibadan, Nigeria. East Afr Med J 1998;75:695-698.

6. Ng'ang'a LW, Odhiambo JA, Omwega MJ, Gicheha CM, Becklake MR, Menzies R et al. Exerciseinduced bron-chospasm: a pilot survey in Nairobi school children. East Afr Med J 1997;74:694-698.

7. Yemaneberhan H, Bekele Z, Venn A, Lewis S, Parry E, Britton J. Prevalence of wheeze and asthma and relation to atopy in urban and rural Ethiopia. Lancet 1997;350:85-90.

8. Ehrlic RI, Du Toit D, Jordaan E, Volmink JA, Weinberg EG, Zwarenstein M. Prevalence and reliability of asthma symptoms in primary school children in Cape Town. Int J Epidemiol 1995;24: 1138-1145.

9. Cookson JB, Makoni G. Prevalence of asthma in Rhodesian Africans. Thorax 1980;35:833-837.

10. Miningou SD, Zoubga AZ, Meda $\mathrm{H}$, Meda N, Tiendrebeogo $\mathrm{H}$. Prevalence of asthma in subjects aged 15-64 years in Bobo-Dioulasso (Burkina Faso) in 1998. Rev Pneumol Clin 2002;58 (6 Pt 1): 341-345.

11. Addo-Yobo EO, Custovic A, Taggart SC, Asafo-Agyei AP, Woodcock A. Seasonal variability in exercise test responses in Ghana. Pediatr Allergy Immunol 2002;13:303-306.

12. Burney P, Chinn S, Jarvis D, Luczynska C, Lai E, on behalf of the European Community Respiratory Health Survey. Variations in the prevalence of respiratory symptoms, self reported asthma attacks, and use of asthma medications in the European Community Respiratory Health Survey (ECRHS). Eur Respir J 1996;9:687-695.

13. Asher MI, Keil U, Anderson HR, Beasley R, Crane J, Martinez F et al. International Study of Asthma and Allergies in Childhood (ISAAC): rationale and methods. Eur Respir J 1995;8:483-491.

14. Enarson DA. Fostering a spirit of critical thinking: The ISAAC story. Int J Tuberc Lung Dis 2005;9:1.

15. Beasley R, Keil U, Von Mutius E, Pearce N, ISAAC Steering Committee. Worldwide variation in prevalence of symptoms of asthma, allergic rhinoconjunctivitis and atopic eczema: ISAAC. Lancet 1998;351:1225-1232.

16. Strachan D, Sibbald B, Weiland S, Att-Khaled N, Anabwani G, Anderson HR et al. Worldwide variations in prevalence of symptoms of allergic rhinoconjuncti-vitis in children: The International Study of Asthma and Allergies in Childhood (ISAAC). Pediatr Allergy Immunol 1997;8:161-176.

17. ISAAC Steering Committee. Worldwide variations in the prevalence of asthma symptoms: the International Study of Asthma and Allergies in Childhood (ISAAC). Eur Respir J 1998;12:315-335.

18. Williams H, Robertson C, Stewart A, Att-Khaled N, Anabwani G, Asher I et al. Worldwide variations of symptoms of atopic eczema in the International Study of Asthma and Allergies in Childhood (ISAAC). J Allergy Clin Immunol 1999;103:125-138.

19. Ellwood P, Asher MI, Beasley R, Clayton TO, The ISAAC Steering Committee. The International Study of Asthma and Allergies in Childhood (ISAAC). Int Union Tuberc Lung Dis 2005;9:10-16. 
20. Bouhayad Z, Aichane A, Afif A, Banhouhoud N, Trombati N, Chan Yeung M et al. Prevalence and trend of self-reported asthma and other allergic diseases symptoms in Morocco. ISAAC Phase I and III. Int J Tuberc Lung Dis 2006;10:133-137.

21. Khaldi F, Fakhfakh R, Mattoussi N, Ben Ali B, Zouari S, Khemiri M. Prevalence and severity of asthma, allergic rhinoconjunctivitis and atopic eczema in 'Grand Tunis' schoolchildren: ISAAC. Tunis Med 2005;83:269-273.

22. Weinberg EG. Urbanization and childhood asthma: an African perspective. Allergy Clin Immunol 2000;105 (2 Pt 1): 224-231.

23. Dagoye D, Bekele Z, Woldemichael K, Nida H, Yimam M, Venn AJ et al. Domestic risk factors for wheeze in urban and rural Ethiopian children. QJM 2004;1997:489-498.

24. Mugusi F, Edwards R, Hayes L, Unwin N, Mbanya JC, Whiting D et al. Prevalence of wheeze and self-reported asthma and asthma care in an urban and rural area of Tanzania and Cameroon. Trop Doct 2004;34:209-214.

25. Godfrey RC. Asthma and IgE levels in rural and urban communities of The Gambia. Clin Allergy 1975;5:201-207.

26. Douwes J, Pearce N. Asthma and the westernization 'package'. Int J Epidemiol 2002;31:1098-1102.

27. Joubert JR, de Klerk HC, Malan C. Ascaris lumbricoides and allergic asthma: a new perspective. S Afr Med J 1979;56: 599-602.

28. Dagoye D, Bekele Z, Woldemichael K, Nida H, Yimam M, Hall A et al. Wheezing, allergy, and parasite infection in children in urban and rural Ethiopia. Am J Respir Crit Care Med 2003;167:1369-1373 (Epub 24 Jan 2003).

29. Platts-Mills TA, Erwin E, Heymann P, Woodfolk J. Is the hygiene hypothesis still a viable explanation for the increased prevalence of asthma? Allergy 2005;60 (Suppl. 79):25-31.

30. Weiland SK, Bjorksten B, Brunekreef B, Cookson WO, von Mutius E, Strachan DP, The International Study of Asthma and Allergies in Childhood Phase II Study Group. Phase II of the International Study of Asthma and Allergies in Childhood (ISAAC II): rationale and methods. Eur Respir J 2004;24:406412.

31. Asher M, Montefort S, Bjorksten B, Lai CKW, Strachan DP, ISAAC Phase Three Study Group. Worldwide time trends in the prevalence of symptoms of asthma, allergic rhinoconjunctivitis, and eczema in childhood: ISAAC Phases One and Three repeat multicountry cross-sectional surveys. Lancet 2006;368: 733-743. 